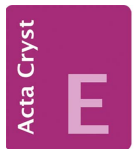

CRYSTALLOGRAPHIC COMMUNICATIONS

ISSN 2056-9890
Received 31 January 2019

Accepted 14 February 2019

Edited by A. J. Lough, University of Toronto, Canada

Keywords: crystal structure; dihydrobenzothiazine; hydrogen bond; DFT; Hirshfeld surface.

CCDC reference: 1897371

Supporting information: this article has supporting information at journals.iucr.org/e

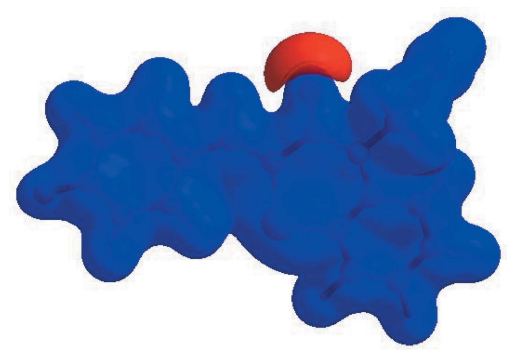

OPEN $\odot$ ACCESS

\section{Crystal structure, Hirshfeld surface analysis and DFT study of (2Z)-2-(4-fluorobenzylidene)-4-(prop- 2-yn-1-yl)-3,4-dihydro-2H-1,4-benzothiazin-3-one}

\author{
Brahim Hni, ${ }^{a} *$ Nada Kheira Sebbar, ${ }^{\mathrm{b}, \mathrm{a}}$ Tuncer Hökelek, ${ }^{\mathrm{c}}$ Younes Ouzidan, ${ }^{\mathrm{d}}$ Ahmed \\ Moussaif, ${ }^{e}$ Joel T. Mague ${ }^{f}$ and El Mokhtar Essassi ${ }^{a, g}$
}

\begin{abstract}
aLaboratoire de Chimie Organique Hétérocyclique URAC 21, Pôle de Compétence Pharmacochimie, Av. Ibn Battouta, BP 1014, Faculté des Sciences, Université Mohammed V, Rabat, Morocco, 'baboratoire de Chimie Bioorganique Appliquée, Faculté des Sciences, Université Ibn Zohr, Agadir, Morocco, 'Department of Physics, Hacettepe University, 06800 Beytepe, Ankara, Turkey, 'Laboratoire de Chimie Organique Appliquée, Université Sidi Mohamed Ben Abdallah, Faculté des Sciences et Techniques, Route d'immouzzer, BP 2202, Fez, Morocco, ${ }^{\mathbf{e}}$ National Center of Energy Sciences and Nuclear Techniques, Rabat, Morocco, '́tDepartment of Chemistry, Tulane University, New Orleans, LA 70118, USA, and ${ }^{\mathbf{g}}$ Moroccan Foundation for Advanced Science, Innovation and Research (MASCIR), Rabat, Morocco. *Correspondence e-mail: brahimhni2018@gmail.com
\end{abstract}

The title compound, $\mathrm{C}_{18} \mathrm{H}_{12} \mathrm{FNOS}$, is built up from a 4-fluorobenzylidene moiety and a dihydrobenzothiazine unit with a propynyl substituent, with the heterocyclic portion of the dihydrobenzothiazine unit adopting a shallow boat conformation with the propynyl substituent nearly perpendicular to it. The two benzene rings are oriented at a dihedral angle of $43.02(6)^{\circ}$. In the crystal, C$\mathrm{H}_{\text {Flurphen }} \cdots \mathrm{F}_{\text {Flurphen }}$ (Flurphen $=$ fluorophenyl) hydrogen bonds link the molecules into inversion dimers, enclosing $R_{2}^{2}(8)$ ring motifs, with the dimers forming oblique stacks along the $a$-axis direction. Hirshfeld surface analysis of the crystal structure indicates that the most important contributions to the crystal packing are from $\mathrm{H} \cdots \mathrm{H}(33.9 \%), \mathrm{H} \cdots \mathrm{C} / \mathrm{C} \cdots \mathrm{H}(26.7 \%), \mathrm{H} \cdots \mathrm{F} / \mathrm{F} \cdots \mathrm{H}$ $(10.9 \%)$ and C . C (10.6\%) interactions. Hydrogen bonding and van der Waals interactions are the dominant interactions in the crystal packing. Density functional theory (DFT) optimized structures at the B3LYP/6-311 G(d,p) level are compared with the experimentally determined molecular structure in the solid state. The HOMO-LUMO behaviour was elucidated to determine the energy gap.

\section{Chemical context}

1,4-Benzothiazine derivatives represent one of the most important classes of organic molecules and have been studied extensively for their biological activities (Ellouz et al., 2017a; Sebbar et al., 2016a) and therapeutic applications such as analgesic (Wammack et al., 2002), anti-viral (Malagu et al., 1998; Rathore \& Kumar, 2006) and anti-oxidant activities (Zia-ur-Rehman et al., 2009). Slight changes in the substitution pattern in the benzothiazine nucleus can cause a distinguishable difference in their biological properties (Niewiadomy et al., 2011; Armenise et al., 2012). Recent research has been focused on existing molecules and their modifications in order to reduce their side effects and to explore their other pharmacological and biological effects (Ellouz et al., 2017b; Sebbar et al., 2016b; Gautam et al., 2012). As a continuation of our research into the development of $\mathrm{N}$-substituted 1,4-benzothiazine derivatives and the evaluation of their potential pharmacological activities, we have studied the condensation reaction of propargyl bromide with (Z)-2-(4-fluorobenzyl- 
idene)-2H-1,4-benzothiazin-3(4H)-one under phase-transfer catalysis conditions using tetra- $n$-butylammonium bromide (TBAB) as catalyst and potassium carbonate as base, leading to the title compound namely (2Z)-2-(4-fluorobenzylidene)-4(prop-2-yn-1-yl)-3,4-dihydro-2H-1,4-benzothiazin-3-one in good yield (Sebbar et al., 2017a, Ellouz et al., 2018), and we report herein its synthesis, the molecular and crystal structures, along with the Hirshfeld surface analysis and density functional theory (DFT) computational calculations carried out at the B3LYP/6-311 G(d,p) level.<smiles>C#CCN1C(=O)/C(=C/c2ccc(F)cc2)Sc2ccccc21</smiles>

\section{Structural commentary}

The title compound, (I), is built up from a 4-fluorophenylmethylidene moiety and a dihydrobenzothiazine unit with a propynyl substituent (Fig. 1$)$. The benzene ( $A$; 1 -C6), ring is oriented at a dihedral angle of $43.02(6)^{\circ}$ with respect to the 4-fluorophenyl ring ( $C ; \mathrm{C} 13-\mathrm{C} 18)$. The propynyl substituent is nearly perpendicular to the plane defined by $\mathrm{C} 1, \mathrm{C} 6, \mathrm{C} 7$ and

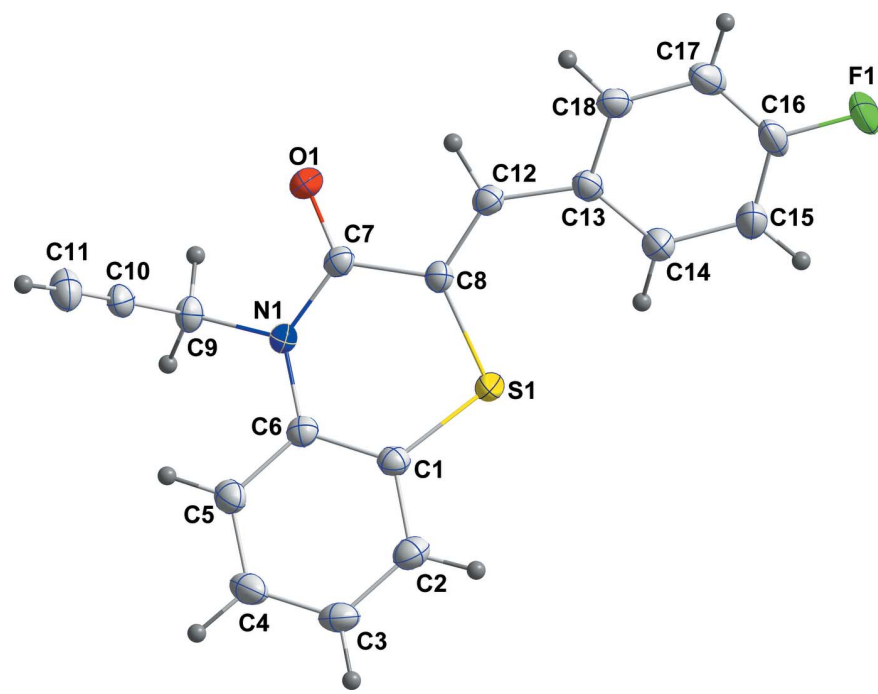

Figure 1

The molecular structure of the title compound with the atom-numbering scheme. Displacement ellipsoids are drawn at the $50 \%$ probability level.
Table 1

Hydrogen-bond geometry $\left(\AA,^{\circ}\right)$.

\begin{tabular}{lllll}
\hline$D-\mathrm{H} \cdots A$ & $D-\mathrm{H}$ & $\mathrm{H} \cdots A$ & $D \cdots A$ & $D-\mathrm{H} \cdots A$ \\
\hline $\mathrm{C} 15-\mathrm{H} 15 \cdots \mathrm{F}^{\mathrm{ii}}$ & $0.98(2)$ & $2.60(2)$ & $3.306(2)$ & $128.5(17)$ \\
\hline
\end{tabular}

Symmetry code: (ii) $-x-1,-y,-z$

$\mathrm{C} 8$, as shown by the $\mathrm{C} 6-\mathrm{N} 1-\mathrm{C} 9-\mathrm{C} 10$ torsion angle of $81.3(2)^{\circ}$. A puckering analysis of the heterocyclic ring $(B ; \mathrm{S} 1 /$ $\mathrm{N} 1 / \mathrm{C} 1 / \mathrm{C} 6-\mathrm{C} 8$ ) of the dihydrobenzothiazine unit shows that it adopts a shallow boat conformation with puckering parameters $Q_{\mathrm{T}}=0.3759$ (14) $\AA, q_{2}=0.3639$ (15) $\AA, q_{3}=$ $-0.0938(17) \AA, \varphi=173.6(3)^{\circ}$ and $\theta=104.5(3)^{\circ}$. In the heterocyclic ring $B$, the $\mathrm{C} 1-\mathrm{S} 1-\mathrm{C} 8\left[101.73(8)^{\circ}\right], \mathrm{S} 1-\mathrm{C} 8-$ C7 $\left[119.93(12)^{\circ}\right], \mathrm{C} 8-\mathrm{C} 7-\mathrm{N} 1\left[119.23(14)^{\circ}\right], \mathrm{C} 7-\mathrm{N} 1-\mathrm{C} 6$ [125.59 (14) $)^{\circ}$ and $\mathrm{C} 6-\mathrm{C} 1-\mathrm{S} 1\left[122.07(13)^{\circ}\right]$ bond angles are enlarged, while the $\mathrm{N} 1-\mathrm{C} 6-\mathrm{C} 1\left[120.91(15)^{\circ}\right]$ bond angle is narrowed when compared with the corresponding values in the closely related compounds 4-methyl-3,4-dihydro- $2 \mathrm{H}-1,4-$ benzothiazin-3-one, (II) (Ellouz et al., 2017b), 4-[(3-phenyl4,5-dihydroisoxazol-5-yl) methyl]-2H-benzo[b][1,4]thiazin3(4H)-one, (III) (Sebbar et al., 2016a) and (Z)-2-(2-chlorobenzylidene)-4-(prop-2-ynyl)-2H-1,4-benzothiazin-3(4H)-one, (IV), (Sebbar et al., 2017a).

\section{Supramolecular features}

In the crystal, $\mathrm{C}-\mathrm{H}_{\text {Flurphen }} \cdots \mathrm{F}_{\text {Flurphen }}$ (Flurphen $=$ fluorophenyl) hydrogen bonds (Table 1) link the molecules into inversion dimers enclosing $R_{2}^{2}(8)$ ring motifs, with the dimers forming oblique stacks along the $a$-axis direction (Figs. 2 and 3).

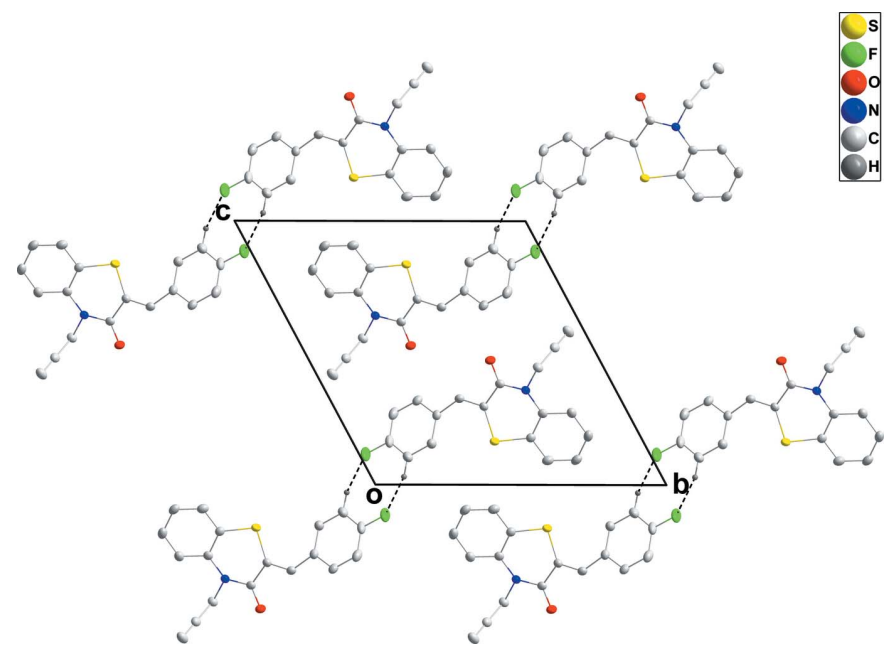

Figure 2

A partial packing diagram viewed along the $a$-axis direction. The intermolecular $\mathrm{C}-\mathrm{H}_{\text {Flurphen }} \cdots \mathrm{F}_{\text {Flurphen }}$ (Flurphen $=$ fluorophenyl) hydrogen bonds are shown as dashed lines. 


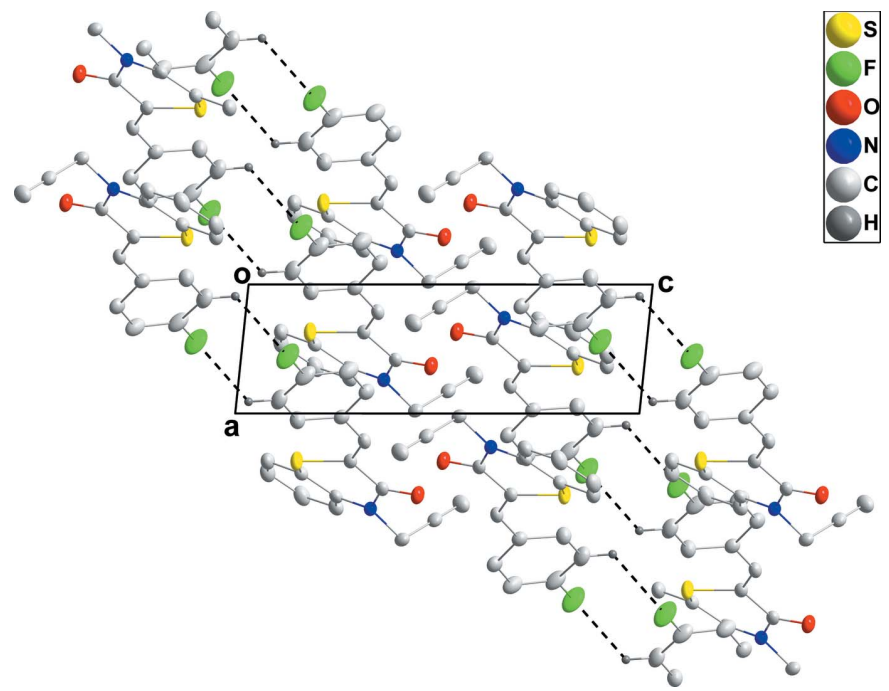

Figure 3

A partial packing diagram viewed along the $b$-axis direction. The intermolecular $\mathrm{C}-\mathrm{H}_{\text {Flurphen }} \cdots \mathrm{F}_{\text {Flurphen }}$ (Flurphen $=$ fluorophenyl) hydrogen bonds are shown as dashed lines.

\section{Hirshfeld surface analysis}

In order to visualize the intermolecular interactions in the crystal of the title compound, a Hirshfeld surface (HS) analysis (Hirshfeld, 1977; Spackman \& Jayatilaka, 2009) was carried out by using CrystalExplorer17.5 (Turner et al., 2017). In the HS plotted over $d_{\text {norm }}$ (Fig. 4), the white surface indicates contacts with distances equal to the sum of van der Waals radii, and the red and blue colours indicate distances shorter (in close contact) or longer (distinct contact) than the van der Waals radii, respectively (Venkatesan et al., 2016). The brightred spots indicate their roles as the respective donors and/or acceptors; they also appear as blue and red regions corresponding to positive and negative potentials on the HS mapped over electrostatic potential (Spackman et al., 2008; Jayatilaka

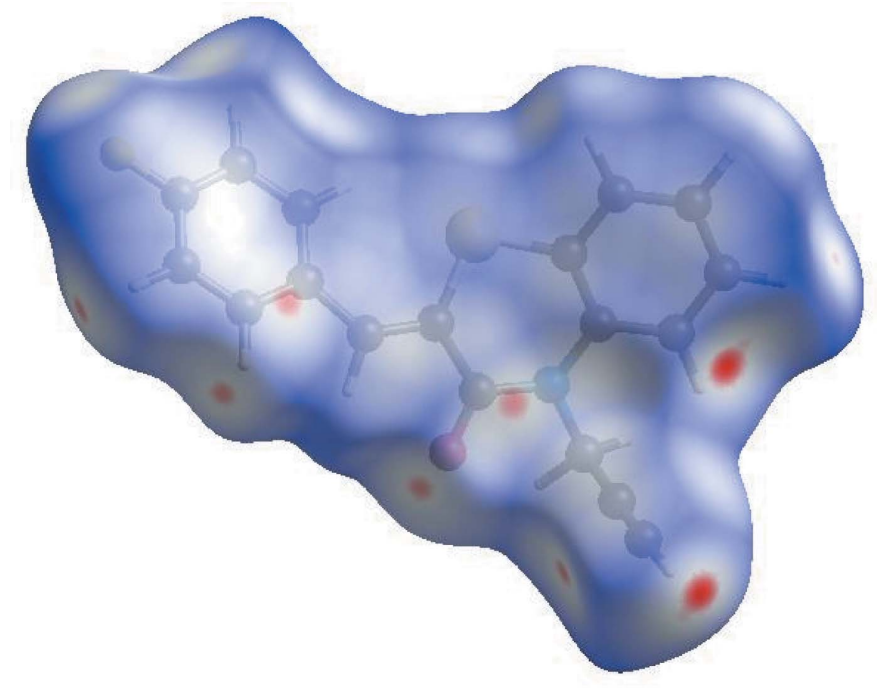

Figure 4

View of the three-dimensional Hirshfeld surface of the title compound plotted over $d_{\text {norm }}$ in the range -0.0943 to 1.2826 a.u.

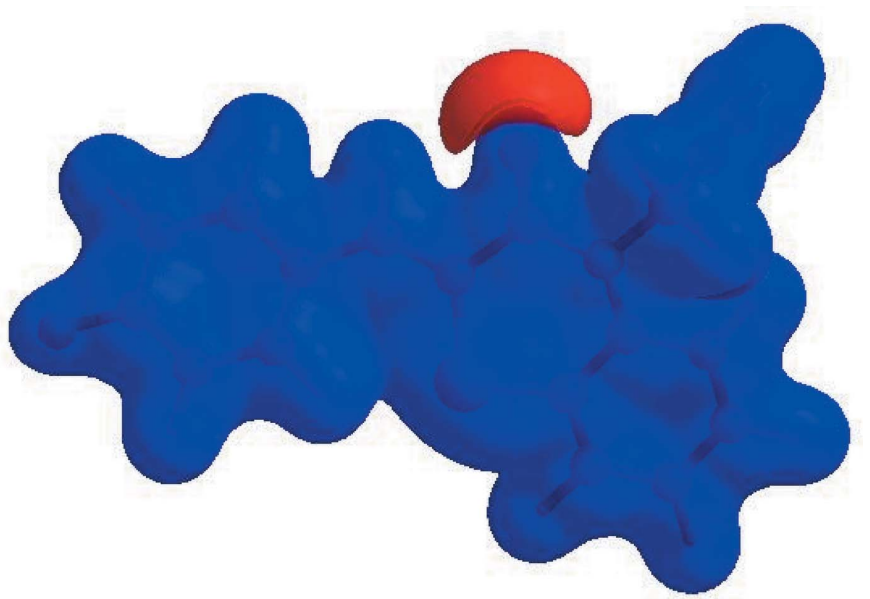

Figure 5

View of the three-dimensional Hirshfeld surface of the title compound plotted over electrostatic potential energy in the range -0.0500 to 0.0500 a.u. using the STO-3 G basis set at the Hartree-Fock level of theory. Hydrogen-bond donors and acceptors are shown as blue and red regions around the atoms corresponding to positive and negative potentials, respectively.

et al., 2005) as shown in Fig. 5. The blue regions indicate the positive electrostatic potential (hydrogen-bond donors), while the red regions indicate the negative electrostatic potential (hydrogen-bond acceptors). The shape-index of the HS is a tool to visualize the $\pi-\pi$ stacking by the presence of adjacent red and blue triangles; if there are no adjacent red and/or blue triangles, then there are no $\pi-\pi$ interactions. Fig. 6 clearly suggest that there are no $\pi-\pi$ interactions in (I).

The overall two-dimensional fingerprint plot, Fig. 7a, and those delineated into $\mathrm{H} \cdots \mathrm{H}, \mathrm{H} \cdots \mathrm{C} / \mathrm{C} \cdots \mathrm{H}, \mathrm{H} \cdots \mathrm{F} / \mathrm{F} \cdots \mathrm{H}$, C. $\cdots \mathrm{C}, \quad \mathrm{H} \cdots \mathrm{O} / \mathrm{O} \cdots \mathrm{H}, \quad \mathrm{H} \cdots \mathrm{S} / \mathrm{S} \cdots \mathrm{H}, \quad \mathrm{C} \cdots \mathrm{N} / \mathrm{N} \cdots \mathrm{C}, \quad \mathrm{C} \cdots \mathrm{S} /$

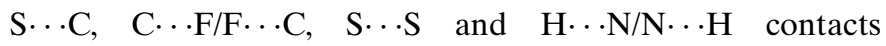
(McKinnon et al., 2007) are illustrated in Fig. 7 b-l, respectively, together with their relative contributions to the Hirshfeld surface. The most important interaction is $\mathrm{H} \cdots \mathrm{H}$ contributing $33.9 \%$ to the overall crystal packing, which is

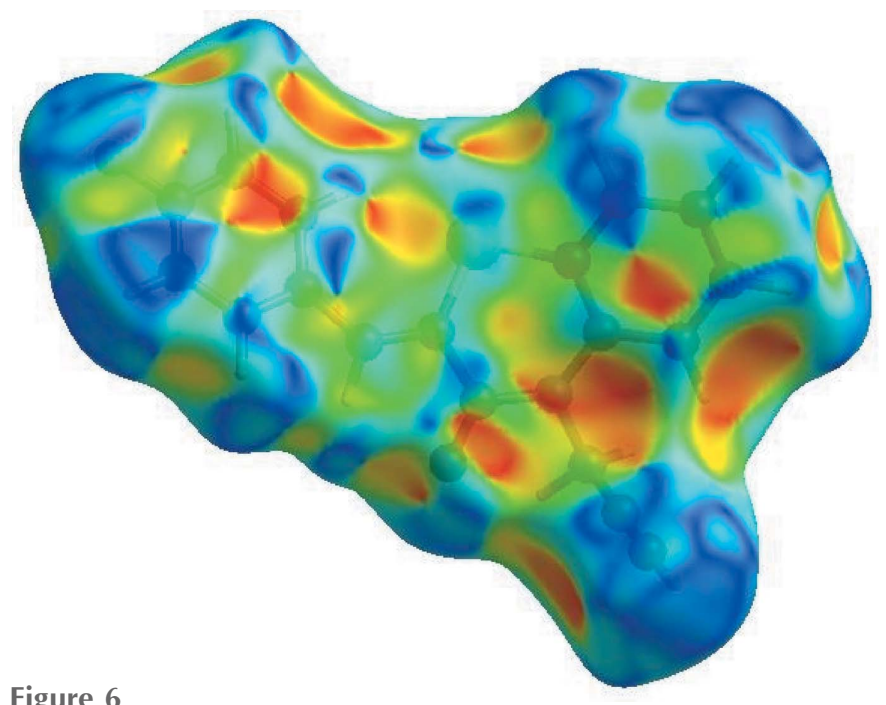

Hirshfeld surface of the title compound plotted over shape-index. 

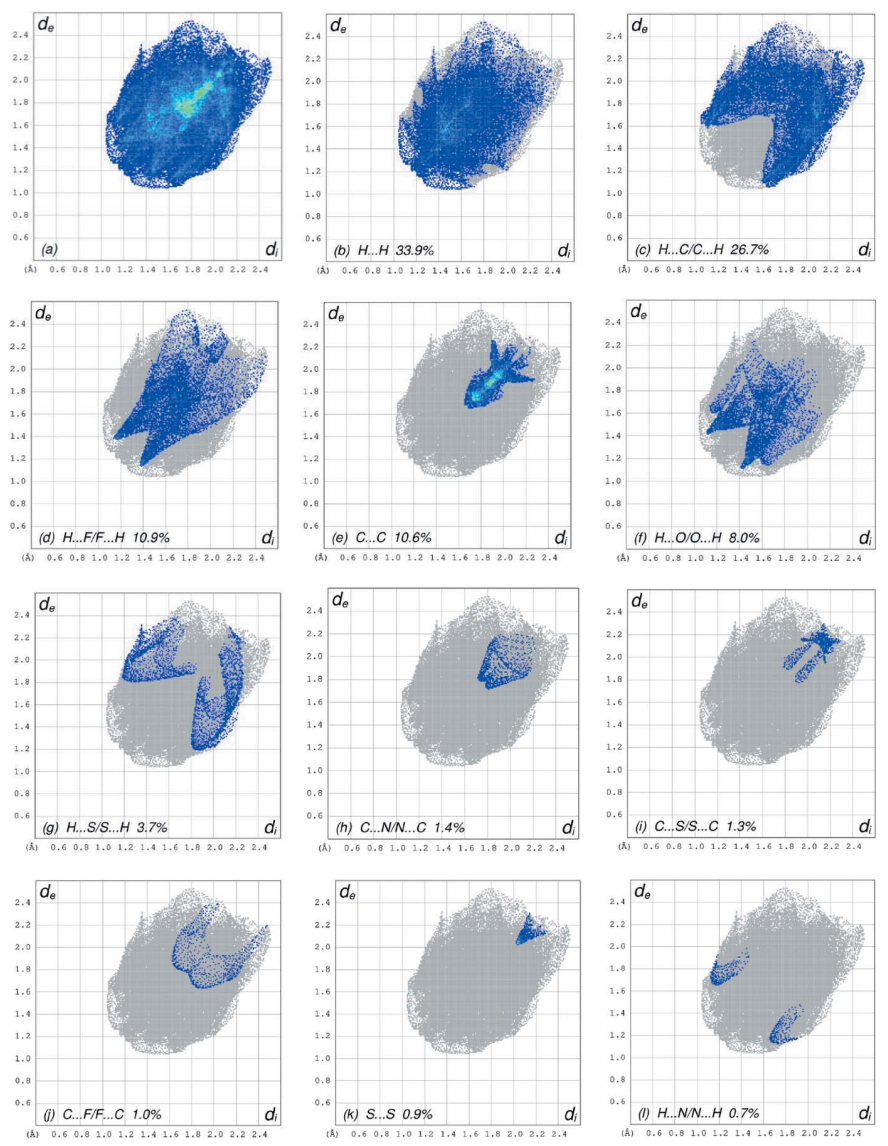

Figure 7

The full two-dimensional fingerprint plots for the title compound, showing $(a)$ all interactions, and delineated into $(b) \mathrm{H} \cdots \mathrm{H},(c) \mathrm{H} \cdots \mathrm{C} /$ $\mathrm{C} \cdots \mathrm{H},(d) \mathrm{H} \cdots \mathrm{F} / \mathrm{F} \cdots \mathrm{H},(e) \mathrm{C} \cdots \mathrm{C},(f) \mathrm{H} \cdots \mathrm{O} / \mathrm{O} \cdots \mathrm{H},(g) \mathrm{H} \cdots \mathrm{S} / \mathrm{S} \cdots \mathrm{H}$, (h) $\mathrm{C} \cdots \mathrm{N} / \mathrm{N} \cdots \mathrm{C},(i) \mathrm{C} \cdots \mathrm{S} / \mathrm{S} \cdots \mathrm{C},(j) \mathrm{C} \cdots \mathrm{F} / \mathrm{F} \cdots \mathrm{C},(k) \mathrm{S} \cdots \mathrm{S}$ and $(l)$ $\mathrm{H} \cdots \mathrm{N} / \mathrm{N} \cdots \mathrm{H}$ interactions. The $d_{\mathrm{i}}$ and $\mathrm{d}_{\mathrm{e}}$ values are the closest internal and external distances (in $\AA$ ) from given points on the Hirshfeld surface.

reflected in Fig. $7 b$ as widely scattered points of high density due to the large hydrogen content of the molecule. In the absence of $\mathrm{C}-\mathrm{H} \cdots \pi$ interactions, the pair of scattered wings in the fingerprint plot delineated into $\mathrm{H} \cdots \mathrm{C} / \mathrm{C} \cdots \mathrm{H}$ contacts ( $26.7 \%$ contribution to the HS) have a nearly symmetrical distribution of points, Fig. $7 c$, with the thick edges at $d_{\mathrm{e}}+d_{\mathrm{i}}$ $\sim 2.70 \AA$. The pair of characteristic wings in the fingerprint plot delineated into $\mathrm{H} \cdots \mathrm{F} / \mathrm{F} \cdots \mathrm{H}$ contacts (Fig. $7 d$, the $10.9 \%$ contribution to the HS) arises from the $\mathrm{C}-\mathrm{H} \cdots \mathrm{F}$ hydrogen bonds (Table 1) as well as from the $\mathrm{H} \cdots \mathrm{F} / \mathrm{F} \cdots \mathrm{H}$ contacts (Table 2) and is shown as a pair of spikes with the tips at $d_{\mathrm{e}}+d_{\mathrm{i}}$ $=2.52 \AA$. The $\mathrm{C} \cdots \mathrm{C}$ contacts (Fig. $7 e, 10.6 \%$ contribution to the HS) have an arrow-shaped distribution of points with the tip at $d_{\mathrm{e}}=d_{\mathrm{i}} \sim 1.68 \AA$. The pair of characteristic wings in the fingerprint plot delineated into $\mathrm{H} \cdots \mathrm{O} / \mathrm{O} \cdots \mathrm{H}$ contacts (Fig. $7 f$, $8.0 \%$ contribution to the HS) have a pair of spikes with the tips at $d_{\mathrm{e}}+d_{\mathrm{i}}=2.54 \AA$. Finally, the $\mathrm{H} \cdots \mathrm{S} / \mathrm{S} \cdots \mathrm{H}$ contacts (Table 2; Fig. 7g, 3.7\% contribution) are viewed as A pair of wide spikes with the tips at $d_{\mathrm{e}}+d_{\mathrm{i}}=3.02 \AA$. The Hirshfeld surface representations with the function $d_{\text {norm }}$ plotted onto the surface are shown for the $\mathrm{H} \cdots \mathrm{H}, \mathrm{H} \cdots \mathrm{C} / \mathrm{C} \cdots \mathrm{H}, \mathrm{H} \cdots \mathrm{F} /$
Table 2

Selected interatomic distances $(\AA)$.

\begin{tabular}{|c|c|c|c|}
\hline 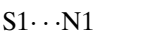 & $3.0702(15)$ & $\mathrm{C} 10 \cdots \mathrm{C} 11^{\mathrm{vii}}$ & $3.572(3)$ \\
\hline S1 $\cdots$ C14 & 3.179 (2) & $\mathrm{C} 12 \cdots \mathrm{C} 18^{\mathrm{vii}}$ & $3.343(3)$ \\
\hline $\mathrm{S} 1 \cdots \mathrm{C} 2^{\mathrm{i}}$ & $3.5158(19)$ & $\mathrm{C} 13 \cdots \mathrm{C} 18^{\mathrm{vii}}$ & $3.464(2)$ \\
\hline $\mathrm{S} 1 \cdots \mathrm{H} 14$ & $2.51(3)$ & $\mathrm{C} 13 \cdots \mathrm{C} 17^{\mathrm{vii}}$ & 3.439 (3) \\
\hline $\mathrm{S} 1 \cdots \mathrm{H} 2^{\mathrm{i}}$ & $3.06(2)$ & $\mathrm{C} 14 \cdots \mathrm{C} 17^{\mathrm{vii}}$ & $3.404(3)$ \\
\hline $\mathrm{F} 1 \cdots \mathrm{F} 1^{\mathrm{ii}}$ & 3.051 (2) & $\mathrm{C} 14 \cdots \mathrm{C} 16^{\mathrm{vii}}$ & 3.457 (3) \\
\hline $\mathrm{F} 1 \cdots \mathrm{C} 15^{\mathrm{ii}}$ & $3.306(3)$ & $\mathrm{C} 15 \cdots \mathrm{C} 16^{\mathrm{vii}}$ & 3.495 (3) \\
\hline $\mathrm{F} 1 \cdots \mathrm{H} 4^{\mathrm{iii}}$ & $2.59(3)$ & $\mathrm{C} 4 \cdots \mathrm{H} 11^{\mathrm{viii}}$ & $2.91(3)$ \\
\hline $\mathrm{F} 1 \cdots \mathrm{H} 15^{\mathrm{ii}}$ & $2.60(2)$ & $\mathrm{C} 5 \cdots \mathrm{H} 9 B$ & $2.63(2)$ \\
\hline $\mathrm{O} 1 \cdots \mathrm{C} 10$ & 3.167 (3) & $\mathrm{C} 5 \cdots \mathrm{H} 11^{\mathrm{viii}}$ & $2.80(3)$ \\
\hline $\mathrm{O} 1 \cdots \mathrm{C} 18^{\mathrm{iv}}$ & $3.388(2)$ & $\mathrm{C} 6 \cdots \mathrm{H} 9 B^{\mathrm{vi}}$ & $2.85(2)$ \\
\hline $\mathrm{O} 1 \cdots \mathrm{C} 18^{\mathrm{v}}$ & $3.261(2)$ & $\mathrm{C} 7 \cdots \mathrm{H} 9 A^{\mathrm{vi}}$ & $2.81(2)$ \\
\hline $\mathrm{O} 1 \cdots \mathrm{H} 12$ & $2.33(2)$ & 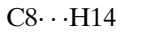 & $2.97(2)$ \\
\hline $\mathrm{O} 1 \cdots \mathrm{H} 9 A^{\mathrm{vi}}$ & $2.83(2)$ & C9..H5 & $2.48(3)$ \\
\hline $\mathrm{O} 1 \cdots \mathrm{H} 9 A$ & $2.26(2)$ & 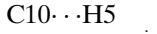 & $2.60(2)$ \\
\hline $\mathrm{O} 1 \cdots \mathrm{H} 12^{\mathrm{v}}$ & $2.70(2)$ & $\mathrm{C} 10 \cdots \mathrm{H} 9 B^{\mathrm{vi}}$ & $2.90(2)$ \\
\hline $\mathrm{O} 1 \cdots \mathrm{H} 18^{\mathrm{iv}}$ & $2.60(2)$ & $\mathrm{C} 11 \cdots \mathrm{H} 5^{\mathrm{ix}}$ & $2.81(3)$ \\
\hline $\mathrm{O} 1 \cdots \mathrm{H} 18^{\mathrm{v}}$ & $2.71(2)$ & $\mathrm{C} 11 \cdots \mathrm{H} 9 B^{\mathrm{vi}}$ & $2.99(2)$ \\
\hline $\mathrm{N} 1 \cdots \mathrm{H} 9 B^{\mathrm{vi}}$ & $2.85(2)$ & $\mathrm{C} 11 \cdots \mathrm{H} 17^{\mathrm{iv}}$ & $2.82(3)$ \\
\hline $\mathrm{C} 5 \cdots \mathrm{C} 10$ & $3.216(2)$ & $\mathrm{H} 2 \cdots \mathrm{H} 2^{\mathrm{x}}$ & 2.57 (4) \\
\hline $\mathrm{C} 7 \cdots \mathrm{C} 12^{\mathrm{vii}}$ & $3.448(3)$ & $\mathrm{H} 5 \cdots \mathrm{H} 9 B$ & $2.17(3)$ \\
\hline $\mathrm{C} 7 \cdots \mathrm{C}^{\mathrm{vi}}$ & 3.334 (3) & $\mathrm{H} 5 \cdots \mathrm{H} 11^{\text {viii }}$ & $2.52(4)$ \\
\hline $\mathrm{C} 9 \cdots \mathrm{C} 10^{\mathrm{vii}}$ & $3.504(2)$ & $\mathrm{H} 9 A \cdots \mathrm{H} 18^{\mathrm{v}}$ & $2.50(3)$ \\
\hline C9...C11 & 3.469 (3) & 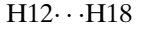 & $2.32(3)$ \\
\hline
\end{tabular}

Symmetry codes: (i) $-x+1,-y+1,-z$; (ii) $-x-1,-y,-z$; (iii) $x-1, y-1, z$; (iv) $-x,-y+1,-z+1$; (v) $-x+1,-y+1,-z+1$; (vi) $x-1, y, z$; (vii) $x+1, y, z$; (vii) $-x+1,-y+2,-z+1 ;$ (ix) $-x+2,-y+2,-z+1 ;(x)-x,-y+1,-z$.

$\mathrm{F} \cdots \mathrm{H}, \mathrm{C} \cdots \mathrm{C}, \mathrm{H} \cdots \mathrm{O} / \mathrm{O} \cdots \mathrm{H}$ and $\mathrm{H} \cdots \mathrm{S} / \mathrm{S} \cdots \mathrm{H}$ interactions in Fig. $8 a-f$, respectively.

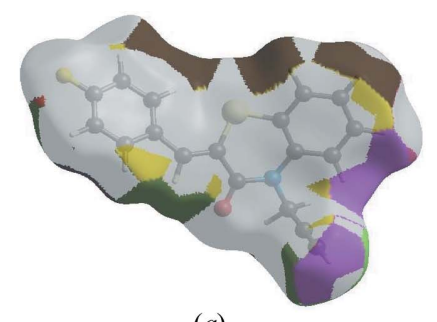

(a)

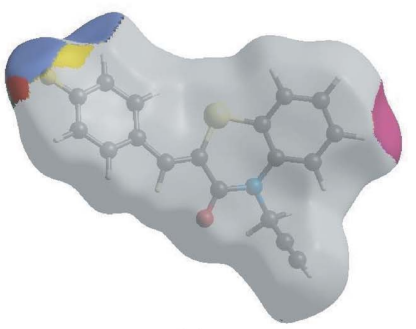

(c)

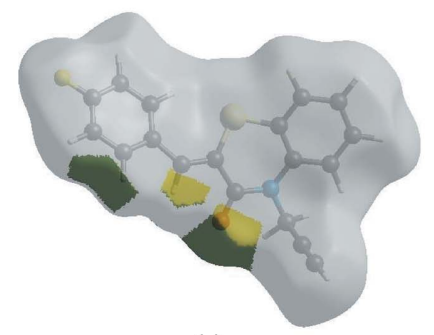

(e)

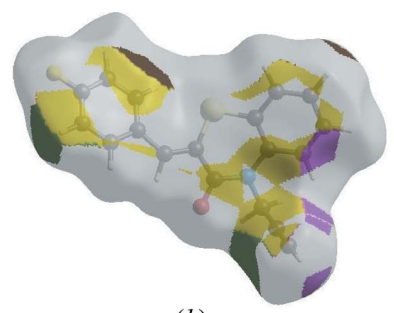

(b)

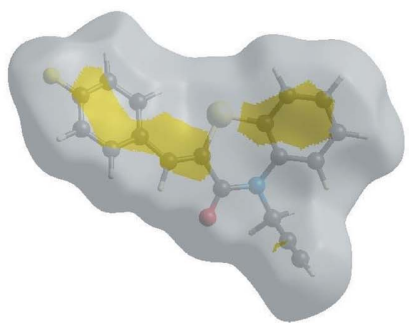

(d)

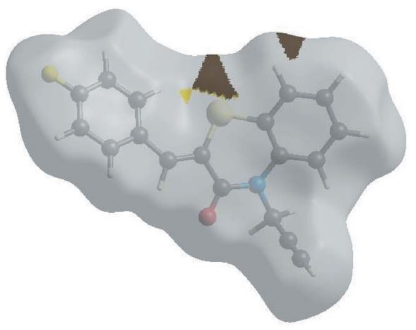

$(f)$
Figure 8

The Hirshfeld surface representations with the function $d_{\text {norm }}$ plotted onto the surface for $(a) \mathrm{H} \cdots \mathrm{H},(b) \mathrm{H} \cdots \mathrm{C} / \mathrm{C} \cdots \mathrm{H},(c) \mathrm{H} \cdots \mathrm{F} / \mathrm{F} \cdots \mathrm{H},(d)$ $\mathrm{C} \cdots \mathrm{C},(e) \mathrm{H} \cdots \mathrm{O} / \mathrm{O} \cdots \mathrm{H}$ and $(f) \mathrm{H} \cdots \mathrm{S} / \mathrm{S} \cdots \mathrm{H}$ interactions. 


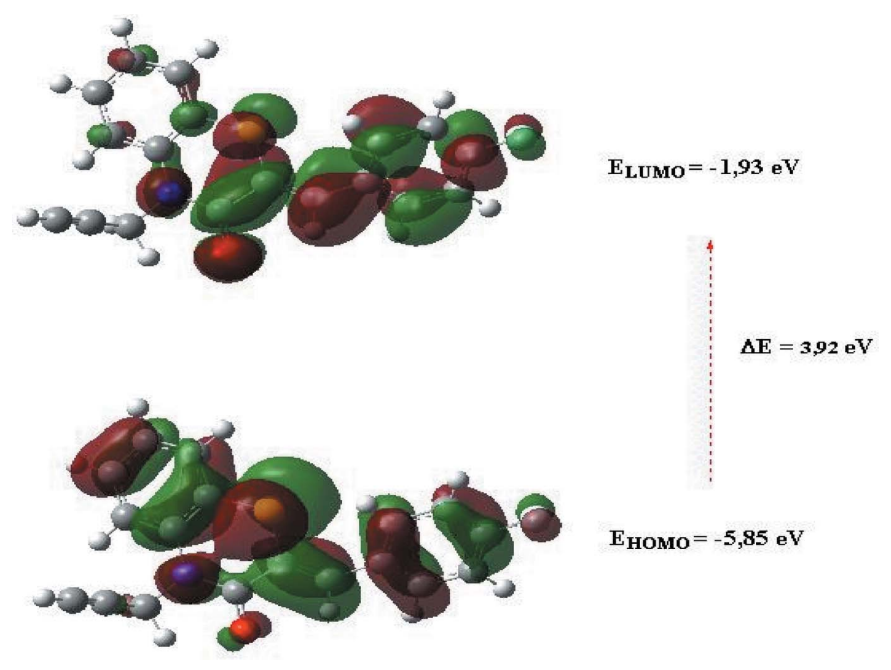

Figure 9

The energy band gap of the title compound.

The Hirshfeld surface analysis confirms the importance of $\mathrm{H}$-atom contacts in establishing the packing. The large number of $\mathrm{H} \cdots \mathrm{H}, \mathrm{H} \cdots \mathrm{C} / \mathrm{C} \cdots \mathrm{H}$ and $\mathrm{H} \cdots \mathrm{O} / \mathrm{O} \cdots \mathrm{H}$ interactions suggest that van der Waals interactions and hydrogen bonding play the major roles in the crystal packing (Hathwar et al., 2015).

\section{DFT calculations}

The optimized structure of the title compound, (I), in the gas phase was generated theoretically via density functional theory (DFT) using standard B3LYP functional and 6$311 \mathrm{G}(\mathrm{d}, \mathrm{p})$ basis-set calculations (Becke, 1993) as implemented in GAUSSIAN 09 (Frisch et al., 2009). The theoretical and experimental results were in good agreement. The highestoccupied molecular orbital (HOMO), acting as an electron donor, and the lowest-unoccupied molecular orbital (LUMO), acting as an electron acceptor, are very important parameters for quantum chemistry. When the energy gap is small, the molecule is highly polarizable and has high chemical reactivity. The electron transition from the HOMO to the LUMO energy level is shown in Fig. 9. The HOMO and LUMO are localized in the plane extending from the whole ( $Z$ )-2-(4-fluorobenzylidene)-4-(prop-2-ynyl)-2H-1,4-benzothiazin-3(4H)-one ring. The energy band gap [ $\left.\Delta E=E_{\mathrm{LUMO}}-E_{\mathrm{HOMO}}\right]$ of the molecule was about $3.92 \mathrm{eV}$, and the frontier molecular orbital energies, $\mathrm{E}_{\mathrm{HOMO}}$ and $\mathrm{E}_{\mathrm{LUMO}}$ were -5.85 and $-1.93 \mathrm{eV}$, respectively.

\section{Database survey}

Using the search fragment II $\left(R_{1}=\mathrm{Ph}, R_{2}=\mathrm{C}\right)$ in the Cambridge Crystallographic Database (Groom et al., 2016; updated to Nov. 2018), 14 hits were registered with $R_{1}=\mathrm{Ph}$ and $R_{2}=\mathrm{CH}_{2} \mathrm{COOH}$ (Sebbar et al., 2016c), IIa (Sebbar et al., 2016b), n-octadecyl (Sebbar et al., 2017b), IIb (Ellouz et al.,
2015), n-Bu (Sebbar, El Fal et al., 2014), IIc (Sebbar et al., 2016d), IId (Sebbar et al., 2015), $\mathrm{CH}_{2} \mathrm{C} \equiv \mathrm{CH}$ IIe (Sebbar, Zerzouf et al., 2014). In addition there are examples with $R_{1}=$ 4- $\mathrm{ClC}_{6} \mathrm{H}_{4}$ and $R_{2}=\mathrm{CH}_{2} \mathrm{Ph} 2$ (Ellouz et al., 2016) IIf and $R_{1}=2$ $\mathrm{ClC}_{6} \mathrm{H}_{4}, R_{2}=\mathrm{CH}_{2} \mathrm{C} \equiv \mathrm{CH}$ (Sebbar et al., 2017c). In the majority of these, the heterocyclic ring is quite non-planar with the dihedral angle between the plane defined by the benzene ring plus the nitrogen and sulfur atoms and that defined by nitrogen and sulfur and the other two carbon atoms separating them ranging from ca. 29 (IIe) to $36^{\circ}$ (IId). The other three (IIa, IIc, IIf) have the benzothiazine unit nearly planar with the corresponding dihedral angle of $c a 3-4^{\circ}$. In the case of IIa, the displacement ellipsoid for the sulfur atom shows a considerable elongation perpendicular to the mean plane of the heterocyclic ring, suggesting disorder, and a greater degree of non-planarity but for the other two, there is no obvious source for the near planarity.<smiles>[R7]C=C1Sc2ccccc2N([Y])C1=O</smiles>

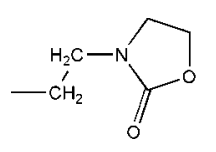

IIa<smiles>CCC1CC(c2ccccc2)=NO1</smiles>

IId

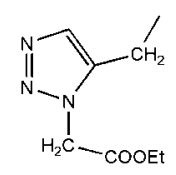

IIb

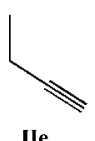

IIe

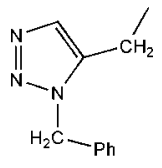

IIc

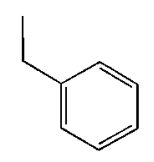

IIf

\section{Synthesis and crystallization}

Propargyl bromide $(4 \mathrm{mmol})$ was added to a mixture of (Z)-2-(4-fluorobenzylidene)-2H-1,4-benzothiazin-3(4H)-one $(1.6 \mathrm{mmol})$, potassium carbonate $(4 \mathrm{mmol})$ and tetra- $n$-butyl ammonium bromide $(0.15 \mathrm{mmol})$ in DMF $(20 \mathrm{ml})$. Stirring was continued at room temperature for $24 \mathrm{~h}$. The salts were removed by filtration and the filtrate was concentrated under reduced pressure. The residue was separated by chromatography on a column of silica gel with ethyl acetate-hexane (2/ 8 ) as eluent. The solid product obtained was recrystallized from ethanol to afford colourless crystals (yield: 89\%).

\section{Refinement}

Crystal data, data collection and structure refinement details are summarized in Table 3. Hydrogen atoms were located in a difference-Fourier map and freely refined.

\section{Funding information}

The support of NSF-MRI grant No. 1228232 for the purchase of the diffractometer and Tulane University for support of the 
Tulane Crystallography Laboratory are gratefully acknowledged. $\mathrm{TH}$ is grateful to the Hacettepe University Scientific Research Project Unit (grant No. 013 D04 602 004).

\section{References}

Armenise, D., Muraglia, M., Florio, M. A., De Laurentis, N., Rosato, A., Carrieri, A., Corbo, F. \& Franchini, C. (2012). Arch. Pharm. Pharm. Med. Chem. 345, 407-416.

Becke, A. D. (1993). J. Chem. Phys. 98, 5648-5652.

Brandenburg, K. \& Putz, H. (2012). DIAMOND, Crystal Impact GbR, Bonn, Germany.

Bruker (2016). APEX3, SAINT and SADABS. Bruker AXS, Inc., Madison, Wisconsin, USA.

Ellouz, M., Sebbar, N. K., Boulhaoua, M., Essassi, E. M. \& Mague, J. T. (2017a). IUCrData, 2, x170646.

Ellouz, M., Sebbar, N. K., Essassi, E. M., Ouzidan, Y. \& Mague, J. T. (2015). Acta Cryst. E71, o1022-o1023.

Ellouz, M., Sebbar, N. K., Essassi, E. M., Ouzidan, Y., Mague, J. T. \& Zouihri, H. (2016). IUCrData, 1, x160764.

Ellouz, M., Sebbar, N. K., Fichtali, I., Ouzidan, Y., Mennane, Z., Charof, R., Mague, J. T., Urrutigoïty, M. \& Essassi, E. M. (2018). Chem. Cent. J. 12, 123.

Ellouz, M., Sebbar, N. K., Ouzidan, Y., Essassi, E. M. \& Mague, J. T. (2017b). IUCrData, 2, x170097.

Frisch, M. J., Trucks, G. W., Schlegel, H. B., Scuseria, G. E., Robb, M. A., Cheeseman, J. R., et al. (2009). GAUSSIAN09. Gaussian Inc., Wallingford, CT, USA.

Gautam, N., Ajmera, N., Gupta, S. \& Gautam, D. C. (2012). Eur. J. Chem. 3, 106-111.

Groom, C. R., Bruno, I. J., Lightfoot, M. P. \& Ward, S. C. (2016). Acta Cryst. B72, 171-179.

Hathwar, V. R., Sist, M., Jørgensen, M. R. V., Mamakhel, A. H., Wang, X., Hoffmann, C. M., Sugimoto, K., Overgaard, J. \& Iversen, B. B. (2015). IUCrJ, 2, 563-574.

Hirshfeld, H. L. (1977). Theor. Chim. Acta, 44, 129-138.

Jayatilaka, D., Grimwood, D. J., Lee, A., Lemay, A., Russel, A. J., Taylor, C., Wolff, S. K., Cassam-Chenai, P. \& Whitton, A. (2005). TONTO - A System for Computational Chemistry. Available at: http://hirshfeldsurface.net/

Krause, L., Herbst-Irmer, R., Sheldrick, G. M. \& Stalke, D. (2015). J. Appl. Cryst. 48, 3-10.

Malagu, K., Boustie, J., David, M., Sauleau, J., Amoros, M., Girre, R. L. \& Sauleau, A. (1998). Pharm. Pharmacol. Commun. 4, 57-60.

McKinnon, J. J., Jayatilaka, D. \& Spackman, M. A. (2007). Chem. Commun. pp. 3814-3816.

Niewiadomy, A., Matysiak, J. \& Karpińska, M. M. (2011). Arch. Pharm. Pharm. Med. Chem. 344, 224-230.

Rathore, B. S. \& Kumar, M. (2006). Bioorg. Med. Chem. 14, 56785682.

Sebbar, N. K., El Fal, M., Essassi, E. M., Saadi, M. \& El Ammari, L. (2014). Acta Cryst. E70, o686.

Sebbar, N. K., Ellouz, M., Boulhaoua, M., Ouzidan, Y., Essassi, E. M. \& Mague, J. T. (2016d). IUCrData, 1, x161823.

Sebbar, N. K., Ellouz, M., Essassi, E. M., Saadi, M. \& El Ammari, L. (2015). Acta Cryst. E71, o423-0424.

Sebbar, N. K., Ellouz, M., Essassi, E. M., Saadi, M. \& El Ammari, L. (2016a). IUCr Data 1, x161012.

Sebbar, N. K., Ellouz, M., Lahmidi, S., Hlimi, F., Essassi, E. \& Mague, J. T. (2017b). IUCrData, 2, x170695.
Table 3

Experimental details.

Crystal data

Chemical formula

$M_{\mathrm{r}}$

Crystal system, space group

Temperature (K)

$a, b, c(\AA)$

$\alpha, \beta, \gamma\left({ }^{\circ}\right)$

$V\left(\AA^{3}\right)$

$Z$

Radiation type

$\mu\left(\mathrm{mm}^{-1}\right)$

Crystal size (mm)

$\mathrm{C}_{18} \mathrm{H}_{12} \mathrm{FNOS}$

309.35

Triclinic, $P \overline{1}$

150

4.0602 (2), 13.8983 (5), 14.2620 (5)

117.809 (2), 93.155 (2), 94.416 (2)

$705.96(5)$

$\mathrm{Cu} K \alpha$

2.15

Data collection

Diffractometer

Absorption correction

$T_{\min }, T_{\max }$

No. of measured, independent and observed $[I>2 \sigma(I)]$ reflections

$R_{\text {int }}$

$(\sin \theta / \lambda)_{\max }\left(\AA^{-1}\right)$

$0.45 \times 0.21 \times 0.01$

Refinement

$R\left[F^{2}>2 \sigma\left(F^{2}\right)\right], w R\left(F^{2}\right), S$

No. of reflections

No. of parameters

$\mathrm{H}$-atom treatment

$\Delta \rho_{\max }, \Delta \rho_{\min }\left(\mathrm{e} \AA^{-3}\right)$

Bruker D8 VENTURE PHOTON 100 CMOS

Numerical (SADABS; Krause et al., 2015)

$0.69,0.97$

$5323,2595,2256$

0.026

0.618

Computer programs: APEX3 and SAINT (Bruker, 2016), SHELXT (Sheldrick, 2015a), SHELXL2018 (Sheldrick, 2015b), DIAMOND (Brandenburg \& Putz, 2012) and SHELXTL (Sheldrick, 2008).

Sebbar, N. K., Ellouz, M., Mague, J. T., Ouzidan, Y., Essassi, E. M. \& Zouihri, H. (2016c). IUCrData, 1, x160863.

Sebbar, N. K., Ellouz, M., Ouzidan, Y., Kaur, M., Essassi, E. M. \& Jasinski, J. P. (2017a). IUCrData, 2, x170889.

Sebbar, N. K., Ellouz, M., Ouzidan, Y., Kaur, M., Essassi, E. M. \& Jasinski, J. P. (2017c). IUCrData, 2, x170889.

Sebbar, N. K., Mekhzoum, M. E. M., Essassi, E. M., Zerzouf, A., Talbaoui, A., Bakri, Y., Saadi, M. \& Ammari, L. E. (2016b). Res. Chem. Intermed. 42, 6845-6862.

Sebbar, N. K., Zerzouf, A., Essassi, E. M., Saadi, M. \& El Ammari, L. (2014). Acta Cryst. E70, o614.

Sheldrick, G. M. (2008). Acta Cryst. A64, 112-122.

Sheldrick, G. M. (2015a). Acta Cryst. A71, 3-8.

Sheldrick, G. M. (2015b). Acta Cryst. C71, 3-8.

Spackman, M. A. \& Jayatilaka, D. (2009). CrystEngComm, 11, 19-32.

Spackman, M. A., McKinnon, J. J. \& Jayatilaka, D. (2008). CrystEngComm, 10, 377-388.

Turner, M. J., McKinnon, J. J., Wolff, S. K., Grimwood, D. J., Spackman, P. R., Jayatilaka, D. \& Spackman, M. A. (2017). CrystalExplorer17. The University of Western Australia.

Venkatesan, P., Thamotharan, S., Ilangovan, A., Liang, H. \& Sundius, T. (2016). Spectrochim. Acta A Mol. Biomol. Spectrosc. 153, 625636.

Wammack, R., Remzi, M., Seitz, C., Djavan, B. \& Marberger, M. (2002). Eur. Urol. 41, 596-601.

Zia-ur-Rehman, M., Choudary, J. A., Elsegood, M. R. J., Siddiqui, H. L. \& Khan, K. M. (2009). Eur. J. Med. Chem. 44, 1311-1316. 


\section{supporting information}

Acta Cryst. (2019). E75, 372-377 [https://doi.org/10.1107/S2056989019002354]

Crystal structure, Hirshfeld surface analysis and DFT study of (2Z)-2-(4-fluorobenzylidene)-4-(prop-2-yn-1-yl)-3,4-dihydro-2H-1,4-benzothiazin-3-one

Brahim Hni, Nada Kheira Sebbar, Tuncer Hökelek, Younes Ouzidan, Ahmed Moussaif, Joel T. Mague and El Mokhtar Essassi

Computing details

Data collection: APEX3 (Bruker, 2016); cell refinement: SAINT (Bruker, 2016); data reduction: SAINT (Bruker, 2016); program(s) used to solve structure: SHELXT (Sheldrick, 2015a); program(s) used to refine structure: SHELXL2018 (Sheldrick, 2015b); molecular graphics: DIAMOND (Brandenburg \& Putz, 2012); software used to prepare material for publication: SHELXTL (Sheldrick, 2008).

(2Z)-2-(4-Fluorobenzylidene)-4-(prop-2-yn-1-yl)-3,4-dihydro-2H-1,4-benzothiazin-3-one

Crystal data

$\mathrm{C}_{18} \mathrm{H}_{12} \mathrm{FNOS}$

$M_{r}=309.35$

Triclinic, $P \overline{1}$

$a=4.0602(2) \AA$

$b=13.8983(5) \AA$

$c=14.2620(5) \AA$

$\alpha=117.809(2)^{\circ}$

$\beta=93.155(2)^{\circ}$

$\gamma=94.416(2)^{\circ}$

$V=705.96(5) \AA^{3}$

Data collection

Bruker D8 VENTURE PHOTON 100 CMOS diffractometer

Radiation source: INCOATEC I $\mu \mathrm{S}$ micro-focus source

Mirror monochromator

Detector resolution: 10.4167 pixels $\mathrm{mm}^{-1}$

$\omega$ scans

Absorption correction: numerical

(SADABS; Krause et al., 2015)

Refinement

Refinement on $F^{2}$

Least-squares matrix: full

$R\left[F^{2}>2 \sigma\left(F^{2}\right)\right]=0.036$

$w R\left(F^{2}\right)=0.092$

$S=1.04$

2595 reflections
$Z=2$

$F(000)=320$

$D_{\mathrm{x}}=1.455 \mathrm{Mg} \mathrm{m}^{-3}$

$\mathrm{Cu} K \alpha$ radiation, $\lambda=1.54178 \AA$

Cell parameters from 4191 reflections

$\theta=3.6-72.3^{\circ}$

$\mu=2.15 \mathrm{~mm}^{-1}$

$T=150 \mathrm{~K}$

Plate, light yellow

$0.45 \times 0.21 \times 0.01 \mathrm{~mm}$

$T_{\min }=0.69, T_{\max }=0.97$

5323 measured reflections

2595 independent reflections

2256 reflections with $I>2 \sigma(I)$

$R_{\text {int }}=0.026$

$\theta_{\max }=72.2^{\circ}, \theta_{\min }=3.6^{\circ}$

$h=-4 \rightarrow 4$

$k=-17 \rightarrow 15$

$l=-15 \rightarrow 17$

247 parameters

0 restraints

Primary atom site location: structure-invariant direct methods

Secondary atom site location: difference Fourier map 
Hydrogen site location: difference Fourier map All $\mathrm{H}$-atom parameters refined $w=1 /\left[\sigma^{2}\left(F_{\mathrm{o}}^{2}\right)+(0.047 P)^{2}+0.2564 P\right]$

where $P=\left(F_{\mathrm{o}}^{2}+2 F_{\mathrm{c}}^{2}\right) / 3$

$$
\begin{aligned}
& (\Delta / \sigma)_{\max }<0.001 \\
& \Delta \rho_{\max }=0.23 \mathrm{e} \AA^{-3} \\
& \Delta \rho_{\min }=-0.31 \mathrm{e} \AA^{-3}
\end{aligned}
$$

\section{Special details}

Geometry. All esds (except the esd in the dihedral angle between two 1.s. planes) are estimated using the full covariance matrix. The cell esds are taken into account individually in the estimation of esds in distances, angles and torsion angles; correlations between esds in cell parameters are only used when they are defined by crystal symmetry. An approximate (isotropic) treatment of cell esds is used for estimating esds involving l.s. planes.

Refinement. Refinement of $\mathrm{F}^{2}$ against ALL reflections. The weighted R-factor wR and goodness of fit $\mathrm{S}$ are based on $\mathrm{F}^{2}$, conventional R-factors $\mathrm{R}$ are based on $\mathrm{F}$, with $\mathrm{F}$ set to zero for negative $\mathrm{F}^{2}$. The threshold expression of $\mathrm{F}^{2}>2$ sigma $\left(\mathrm{F}^{2}\right)$ is used only for calculating R-factors ( $\mathrm{gt}$ ) etc. and is not relevant to the choice of reflections for refinement. R-factors based

\begin{tabular}{|c|c|c|c|c|}
\hline & $x$ & $y$ & $z$ & $U_{\text {iso }} * / U_{\text {eq }}$ \\
\hline S1 & $0.36900(11)$ & $0.48920(3)$ & $0.16432(3)$ & $0.02650(14)$ \\
\hline $\mathrm{F} 1$ & -0.4439 & $0.02242(10)$ & $0.11539(11)$ & $0.0500(4)$ \\
\hline O1 & $0.6330(3)$ & $0.62345(10)$ & $0.47251(9)$ & $0.0274(3)$ \\
\hline N1 & $0.7395(3)$ & $0.69008(11)$ & $0.35897(11)$ & $0.0196(3)$ \\
\hline $\mathrm{C} 1$ & $0.4638(4)$ & $0.62082(14)$ & $0.17880(13)$ & $0.0216(3)$ \\
\hline $\mathrm{C} 2$ & $0.3701(5)$ & $0.63770(16)$ & $0.09280(14)$ & $0.0280(4)$ \\
\hline $\mathrm{H} 2$ & $0.244(6)$ & $0.5760(19)$ & 0.0305 (18) & $0.040(6)^{*}$ \\
\hline $\mathrm{C} 3$ & $0.4589(5)$ & $0.73747(16)$ & $0.09560(15)$ & $0.0302(4)$ \\
\hline H3 & $0.400(5)$ & $0.7482(18)$ & $0.0363(18)$ & $0.035(6)^{*}$ \\
\hline $\mathrm{C} 4$ & $0.6386(5)$ & $0.82155(16)$ & $0.18618(16)$ & $0.0309(4)$ \\
\hline $\mathrm{H} 4$ & $0.717(5)$ & 0.8918 (19) & 0.1894 (17) & $0.037(6)^{*}$ \\
\hline $\mathrm{C} 5$ & $0.7262(4)$ & $0.80684(15)$ & $0.27349(14)$ & $0.0253(4)$ \\
\hline H5 & $0.838(6)$ & 0.8665 (19) & $0.3380(18)$ & $0.034(6)^{*}$ \\
\hline C6 & $0.6440(4)$ & $0.70567(14)$ & $0.27073(13)$ & 0.0200 \\
\hline $\mathrm{C} 7$ & $0.5847(4)$ & $0.61287(13)$ & $0.38287(13)$ & 0.0201 \\
\hline $\mathrm{C} 8$ & $0.3693(4)$ & $0.51633(13)$ & $0.29720(13)$ & 0.0200 \\
\hline C9 & $0.9780(4)$ & $0.77412(14)$ & $0.44531(14)$ & $0.0226(4)$ \\
\hline H9A & $1.078(5)$ & $0.7384(17)$ & $0.4841(16)$ & $0.027(5)^{*}$ \\
\hline H9B & $1.157(5)$ & 0.7991 (17) & $0.4139(16)$ & $0.029(5)^{*}$ \\
\hline $\mathrm{C} 10$ & $0.8244(4)$ & $0.86876(14)$ & $0.52130(13)$ & $0.0232(4)$ \\
\hline $\mathrm{C} 11$ & $0.7008(5)$ & $0.94494(16)$ & $0.58223(16)$ & 0.0323 \\
\hline H11 & $0.598(7)$ & $1.005(2)$ & $0.627(2)$ & $0.058(8)^{*}$ \\
\hline $\mathrm{C} 12$ & $0.2140(4)$ & $0.44701(14)$ & $0.32673(13)$ & $0.0221(4)$ \\
\hline H12 & $0.239(5)$ & $0.4694(17)$ & $0.4023(17)$ & $0.027(5)^{*}$ \\
\hline $\mathrm{C} 13$ & $0.0273(4)$ & $0.33862(14)$ & $0.26424(13)$ & $0.0224(4)$ \\
\hline $\mathrm{C} 14$ & $0.0509(5)$ & $0.26864(15)$ & $0.15586(14)$ & $0.0273(4)$ \\
\hline H14 & $0.190(5)$ & $0.2934(18)$ & 0.1155 (17) & $0.033(6)^{*}$ \\
\hline $\mathrm{C} 15$ & $-0.1081(5)$ & $0.16234(16)$ & $0.10546(16)$ & $0.0317(4)$ \\
\hline H15 & $-0.091(6)$ & 0.1127 (19) & 0.0299 (19) & $0.041(6)^{*}$ \\
\hline $\mathrm{C} 16$ & $-0.2926(5)$ & $0.12750(16)$ & $0.16410(17)$ & $0.0337(4)$ \\
\hline $\mathrm{C} 17$ & $-0.3307(5)$ & $0.19315(17)$ & $0.26970(16)$ & $0.0334(4)$ \\
\hline
\end{tabular}
on $\mathrm{F}^{2}$ are statistically about twice as large as those based on F, and R-factors based on ALL data will be even larger.

Fractional atomic coordinates and isotropic or equivalent isotropic displacement parameters $\left(\AA^{2}\right)$ 


\begin{tabular}{lllll}
$\mathrm{H} 17$ & $-0.461(6)$ & $0.166(2)$ & $0.3075(19)$ & $0.046(7)^{*}$ \\
$\mathrm{C} 18$ & $-0.1680(4)$ & $0.29876(15)$ & $0.31937(15)$ & $0.0258(4)$ \\
$\mathrm{H} 18$ & $-0.184(5)$ & $0.3440(17)$ & $0.3957(18)$ & $0.029(5)^{*}$ \\
\hline
\end{tabular}

Atomic displacement parameters $\left(\AA^{2}\right)$

\begin{tabular}{lllllll}
\hline & $U^{11}$ & $U^{22}$ & $U^{33}$ & $U^{12}$ & $U^{13}$ & $U^{23}$ \\
\hline S1 & $0.0385(3)$ & $0.0213(2)$ & $0.0162(2)$ & $-0.00484(17)$ & $0.00200(16)$ & $0.00729(18)$ \\
F1 & $0.0686(9)$ & $0.0280(6)$ & $0.0495(8)$ & $-0.0221(6)$ & $-0.0186(6)$ & $0.0217(6)$ \\
O1 & $0.0346(7)$ & $0.0275(7)$ & $0.0186(6)$ & $-0.0014(5)$ & $-0.0013(5)$ & $0.0108(5)$ \\
N1 & $0.0214(7)$ & $0.0177(7)$ & $0.0176(7)$ & $0.0015(5)$ & $0.0016(5)$ & $0.0067(6)$ \\
C1 & $0.0221(8)$ & $0.0235(9)$ & $0.0208(8)$ & $0.0027(6)$ & $0.0047(6)$ & $0.0114(7)$ \\
C2 & $0.0297(10)$ & $0.0330(10)$ & $0.0214(9)$ & $0.0033(7)$ & $0.0040(7)$ & $0.0129(8)$ \\
C3 & $0.0378(11)$ & $0.0351(11)$ & $0.0255(9)$ & $0.0094(8)$ & $0.0076(7)$ & $0.0197(9)$ \\
C4 & $0.0426(11)$ & $0.0257(10)$ & $0.0311(10)$ & $0.0083(8)$ & $0.0130(8)$ & $0.0173(9)$ \\
C5 & $0.0291(9)$ & $0.0214(9)$ & $0.0247(9)$ & $0.0035(7)$ & $0.0070(7)$ & $0.0097(8)$ \\
C6 & $0.0190(8)$ & $0.0212(8)$ & $0.0195(8)$ & $0.0044(6)$ & $0.0055(6)$ & $0.0087(7)$ \\
C7 & $0.0214(8)$ & $0.0202(8)$ & $0.0182(8)$ & $0.0054(6)$ & $0.0032(6)$ & $0.0080(7)$ \\
C8 & $0.0220(8)$ & $0.0178(8)$ & $0.0188(8)$ & $0.0030(6)$ & $0.0025(6)$ & $0.0073(7)$ \\
C9 & $0.0198(8)$ & $0.0208(8)$ & $0.0229(8)$ & $-0.0001(6)$ & $-0.0004(6)$ & $0.0075(7)$ \\
C10 & $0.0225(8)$ & $0.0215(9)$ & $0.0227(8)$ & $-0.0046(6)$ & $-0.0010(6)$ & $0.0095(7)$ \\
C11 & $0.0336(11)$ & $0.0231(10)$ & $0.0321(10)$ & $-0.0004(8)$ & $0.0083(8)$ & $0.0064(9)$ \\
C12 & $0.0259(9)$ & $0.0224(9)$ & $0.0182(8)$ & $0.0044(6)$ & $0.0044(6)$ & $0.0092(7)$ \\
C13 & $0.0229(8)$ & $0.0214(9)$ & $0.0248(9)$ & $0.0011(6)$ & $-0.0006(6)$ & $0.0131(7)$ \\
C14 & $0.0338(10)$ & $0.0230(9)$ & $0.0248(9)$ & $0.0007(7)$ & $0.0035(7)$ & $0.0115(8)$ \\
C15 & $0.0413(11)$ & $0.0219(9)$ & $0.0271(10)$ & $-0.0005(8)$ & $-0.0038(8)$ & $0.0088(8)$ \\
C16 & $0.0401(11)$ & $0.0216(9)$ & $0.0393(11)$ & $-0.0087(8)$ & $-0.0132(8)$ & $0.0178(8)$ \\
C17 & $0.0338(10)$ & $0.0346(11)$ & $0.0381(11)$ & $-0.0079(8)$ & $-0.0064(8)$ & $0.0253(10)$ \\
C18 & $0.0273(9)$ & $0.0293(10)$ & $0.0252(9)$ & $0.0007(7)$ & $-0.0013(7)$ & $0.0173(8)$ \\
& & & & & & \\
\hline
\end{tabular}

Geometric parameters $\left(A,{ }^{\circ}\right)$

\begin{tabular}{llll}
\hline $\mathrm{S} 1-\mathrm{C} 8$ & $1.7511(17)$ & $\mathrm{C} 8-\mathrm{C} 12$ & $1.348(2)$ \\
$\mathrm{S} 1-\mathrm{C} 1$ & $1.7515(17)$ & $\mathrm{C} 9-\mathrm{C} 10$ & $1.471(2)$ \\
$\mathrm{F} 1-\mathrm{C} 16$ & $1.364(2)$ & $\mathrm{C} 9-\mathrm{H} 9 \mathrm{~A}$ & $0.99(2)$ \\
$\mathrm{O} 1-\mathrm{C} 7$ & $1.219(2)$ & $\mathrm{C} 9-\mathrm{H} 9 \mathrm{~B}$ & $0.99(2)$ \\
$\mathrm{N} 1-\mathrm{C} 7$ & $1.387(2)$ & $\mathrm{C} 10-\mathrm{C} 11$ & $1.183(3)$ \\
$\mathrm{N} 1-\mathrm{C} 6$ & $1.412(2)$ & $\mathrm{C} 11-\mathrm{H} 11$ & $0.93(3)$ \\
$\mathrm{N} 1-\mathrm{C} 9$ & $1.473(2)$ & $\mathrm{C} 12-\mathrm{C} 13$ & $1.461(2)$ \\
$\mathrm{C} 1-\mathrm{C} 2$ & $1.391(2)$ & $\mathrm{C} 12-\mathrm{H} 12$ & $0.97(2)$ \\
$\mathrm{C} 1-\mathrm{C} 6$ & $1.401(2)$ & $\mathrm{C} 13-\mathrm{C} 18$ & $1.400(2)$ \\
$\mathrm{C} 2-\mathrm{C} 3$ & $1.387(3)$ & $\mathrm{C} 13-\mathrm{C} 14$ & $1.404(2)$ \\
$\mathrm{C} 2-\mathrm{H} 2$ & $0.98(2)$ & $\mathrm{C} 14-\mathrm{C} 15$ & $1.388(3)$ \\
$\mathrm{C} 3-\mathrm{C} 4$ & $1.387(3)$ & $\mathrm{C} 14-\mathrm{H} 14$ & $0.98(2)$ \\
$\mathrm{C} 3-\mathrm{H} 3$ & $0.95(2)$ & $\mathrm{C} 15-\mathrm{C} 16$ & $1.373(3)$ \\
$\mathrm{C} 4-\mathrm{C} 5$ & $1.385(3)$ & $\mathrm{C} 15-\mathrm{H} 15$ & $0.98(2)$ \\
$\mathrm{C} 4-\mathrm{H} 4$ & $0.98(2)$ & $\mathrm{C} 16-\mathrm{C} 17$ & $1.375(3)$ \\
$\mathrm{C} 5-\mathrm{C} 6$ & $1.402(2)$ & $\mathrm{C} 17-\mathrm{C} 18$ & $1.386(3)$
\end{tabular}




\begin{tabular}{|c|c|c|c|}
\hline $\mathrm{C} 5-\mathrm{H} 5$ & $0.96(2)$ & C17-H17 & $0.95(2)$ \\
\hline $\mathrm{C} 7-\mathrm{C} 8$ & $1.493(2)$ & C18-H18 & $0.98(2)$ \\
\hline $\mathrm{S} 1 \cdots \mathrm{N} 1$ & $3.0702(15)$ & $\mathrm{C} 10 \cdots \mathrm{C} 11^{\mathrm{vii}}$ & $3.572(3)$ \\
\hline $\mathrm{S} 1 \cdots \mathrm{C} 14$ & $3.179(2)$ & $\mathrm{C} 12 \cdots \mathrm{C} 18^{\text {vii }}$ & $3.343(3)$ \\
\hline $\mathrm{S} 1 \cdots \mathrm{C} 2^{\mathrm{i}}$ & $3.5158(19)$ & $\mathrm{C} 13 \cdots \mathrm{C} 18^{\mathrm{vii}}$ & $3.464(2)$ \\
\hline $\mathrm{S} 1 \cdots \mathrm{H} 14$ & $2.51(3)$ & $\mathrm{C} 13 \cdots \mathrm{C} 17^{\mathrm{vii}}$ & $3.439(3)$ \\
\hline $\mathrm{S} 1 \cdots \mathrm{H} 2^{\mathrm{i}}$ & $3.06(2)$ & $\mathrm{C} 14 \cdots \mathrm{C} 17^{\mathrm{vii}}$ & $3.404(3)$ \\
\hline $\mathrm{F} 1 \cdots \mathrm{F} 1^{\mathrm{ii}}$ & $3.051(2)$ & $\mathrm{C} 14 \cdots \mathrm{C} 16^{\mathrm{vii}}$ & $3.457(3)$ \\
\hline $\mathrm{F} 1 \cdots \mathrm{C} 15^{\mathrm{ii}}$ & $3.306(3)$ & $\mathrm{C} 15 \cdots \mathrm{C} 16^{\mathrm{vii}}$ & $3.495(3)$ \\
\hline $\mathrm{F} 1 \cdots \mathrm{H} 4^{\mathrm{iii}}$ & $2.59(3)$ & $\mathrm{C} 4 \cdots \mathrm{H} 11^{\mathrm{viii}}$ & $2.91(3)$ \\
\hline $\mathrm{F} 1 \cdots \mathrm{H} 15^{\mathrm{ii}}$ & $2.60(2)$ & C5 $\cdots$ H9B & $2.63(2)$ \\
\hline $\mathrm{O} 1 \cdots \mathrm{C} 10$ & $3.167(3)$ & $\mathrm{C} 5 \cdots \mathrm{H} 11^{\mathrm{viii}}$ & $2.80(3)$ \\
\hline $\mathrm{O} 1 \cdots \mathrm{C} 18^{\mathrm{iv}}$ & $3.388(2)$ & $\mathrm{C} 6 \cdots \mathrm{H} 9 \mathrm{~B}^{\mathrm{vi}}$ & $2.85(2)$ \\
\hline $\mathrm{O} 1 \cdots \mathrm{C} 18^{\mathrm{v}}$ & $3.261(2)$ & $\mathrm{C} 7 \cdots \mathrm{H} 9 \mathrm{~A}^{\mathrm{vi}}$ & $2.81(2)$ \\
\hline $\mathrm{O} 1 \cdots \mathrm{H} 12$ & $2.33(2)$ & C $8 \cdots \mathrm{H} 14$ & $2.97(2)$ \\
\hline 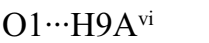 & $2.83(2)$ & 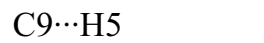 & $2.48(3)$ \\
\hline 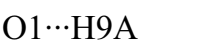 & $2.26(2)$ & $\mathrm{C} 10 \cdots \mathrm{H} 5$ & $2.60(2)$ \\
\hline $\mathrm{O} 1 \cdots \mathrm{H} 12^{\mathrm{v}}$ & $2.70(2)$ & $\mathrm{C} 10 \cdots \mathrm{H}_{9} \mathrm{~B}^{\mathrm{vi}}$ & $2.90(2)$ \\
\hline $\mathrm{O} 1 \cdots \mathrm{H} 18^{\mathrm{iv}}$ & $2.60(2)$ & $\mathrm{C} 11 \cdots \mathrm{H} 5^{\mathrm{ix}}$ & $2.81(3)$ \\
\hline $\mathrm{O} 1 \cdots \mathrm{H} 18^{\mathrm{v}}$ & $2.71(2)$ & $\mathrm{C} 11 \cdots \mathrm{H}_{9} \mathrm{~B}^{\mathrm{vi}}$ & $2.99(2)$ \\
\hline $\mathrm{N} 1 \cdots \mathrm{H} \mathrm{B}^{\mathrm{vi}}$ & $2.85(2)$ & $\mathrm{C} 11 \cdots \mathrm{H} 17^{\mathrm{iv}}$ & $2.82(3)$ \\
\hline $\mathrm{C} 5 \cdots \mathrm{C} 10$ & $3.216(2)$ & $\mathrm{H} 2 \cdots H 2^{\mathrm{x}}$ & $2.57(4)$ \\
\hline $\mathrm{C} 7 \cdots \mathrm{C} 12^{\mathrm{vii}}$ & $3.448(3)$ & H5 $\cdots H 9 B$ & $2.17(3)$ \\
\hline $\mathrm{C} 7 \cdots \mathrm{C}^{\mathrm{vi}}$ & $3.334(3)$ & $\mathrm{H} 5 \cdots \mathrm{H} 11^{\mathrm{viii}}$ & $2.52(4)$ \\
\hline $\mathrm{C} 9 \cdots \mathrm{C} 10^{\mathrm{vii}}$ & $3.504(2)$ & $\mathrm{H} 9 \mathrm{~A} \cdots \mathrm{H} 18^{\mathrm{v}}$ & $2.50(3)$ \\
\hline $\mathrm{C} 9 \cdots \mathrm{C} 11^{\mathrm{vii}}$ & $3.469(3)$ & $\mathrm{H} 12 \cdots \mathrm{H} 18$ & $2.32(3)$ \\
\hline $\mathrm{C} 8-\mathrm{S} 1-\mathrm{C} 1$ & $101.73(8)$ & $\mathrm{C} 10-\mathrm{C} 9-\mathrm{H} 9 \mathrm{~A}$ & $108.6(12)$ \\
\hline $\mathrm{C} 7-\mathrm{N} 1-\mathrm{C} 6$ & $125.59(14)$ & $\mathrm{N} 1-\mathrm{C} 9-\mathrm{H} 9 \mathrm{~A}$ & $106.8(12)$ \\
\hline $\mathrm{C} 7-\mathrm{N} 1-\mathrm{C} 9$ & $114.59(13)$ & $\mathrm{C} 10-\mathrm{C} 9-\mathrm{H} 9 \mathrm{~B}$ & $109.9(12)$ \\
\hline $\mathrm{C} 6-\mathrm{N} 1-\mathrm{C} 9$ & $118.68(14)$ & $\mathrm{N} 1-\mathrm{C} 9-\mathrm{H} 9 \mathrm{~B}$ & $109.3(12)$ \\
\hline $\mathrm{C} 2-\mathrm{C} 1-\mathrm{C} 6$ & $120.19(16)$ & $\mathrm{H} 9 \mathrm{~A}-\mathrm{C} 9-\mathrm{H} 9 \mathrm{~B}$ & $108.7(17)$ \\
\hline $\mathrm{C} 2-\mathrm{C} 1-\mathrm{S} 1$ & $117.64(14)$ & $\mathrm{C} 11-\mathrm{C} 10-\mathrm{C} 9$ & $179.8(2)$ \\
\hline $\mathrm{C} 6-\mathrm{C} 1-\mathrm{S} 1$ & $122.07(13)$ & $\mathrm{C} 10-\mathrm{C} 11-\mathrm{H} 11$ & $177.1(17)$ \\
\hline $\mathrm{C} 3-\mathrm{C} 2-\mathrm{C} 1$ & $120.78(17)$ & $\mathrm{C} 8-\mathrm{C} 12-\mathrm{C} 13$ & $131.55(16)$ \\
\hline $\mathrm{C} 3-\mathrm{C} 2-\mathrm{H} 2$ & $122.1(14)$ & $\mathrm{C} 8-\mathrm{C} 12-\mathrm{H} 12$ & $115.9(12)$ \\
\hline $\mathrm{C} 1-\mathrm{C} 2-\mathrm{H} 2$ & $117.1(14)$ & $\mathrm{C} 13-\mathrm{C} 12-\mathrm{H} 12$ & $112.4(12)$ \\
\hline $\mathrm{C} 4-\mathrm{C} 3-\mathrm{C} 2$ & $119.25(17)$ & $\mathrm{C} 18-\mathrm{C} 13-\mathrm{C} 14$ & $117.96(16)$ \\
\hline $\mathrm{C} 4-\mathrm{C} 3-\mathrm{H} 3$ & $120.1(14)$ & $\mathrm{C} 18-\mathrm{C} 13-\mathrm{C} 12$ & $116.92(16)$ \\
\hline $\mathrm{C} 2-\mathrm{C} 3-\mathrm{H} 3$ & $120.7(14)$ & $\mathrm{C} 14-\mathrm{C} 13-\mathrm{C} 12$ & $124.90(16)$ \\
\hline $\mathrm{C} 5-\mathrm{C} 4-\mathrm{C} 3$ & $120.61(17)$ & $\mathrm{C} 15-\mathrm{C} 14-\mathrm{C} 13$ & $121.06(17)$ \\
\hline $\mathrm{C} 5-\mathrm{C} 4-\mathrm{H} 4$ & $117.9(13)$ & $\mathrm{C} 15-\mathrm{C} 14-\mathrm{H} 14$ & $118.9(13)$ \\
\hline $\mathrm{C} 3-\mathrm{C} 4-\mathrm{H} 4$ & $121.4(13)$ & $\mathrm{C} 13-\mathrm{C} 14-\mathrm{H} 14$ & $119.9(13)$ \\
\hline $\mathrm{C} 4-\mathrm{C} 5-\mathrm{C} 6$ & $120.64(17)$ & $\mathrm{C} 16-\mathrm{C} 15-\mathrm{C} 14$ & $118.26(18)$ \\
\hline $\mathrm{C} 4-\mathrm{C} 5-\mathrm{H} 5$ & $120.7(14)$ & $\mathrm{C} 16-\mathrm{C} 15-\mathrm{H} 15$ & $120.2(14)$ \\
\hline $\mathrm{C} 6-\mathrm{C} 5-\mathrm{H} 5$ & $118.6(14)$ & $\mathrm{C} 14-\mathrm{C} 15-\mathrm{H} 15$ & $121.5(14)$ \\
\hline $\mathrm{C} 1-\mathrm{C} 6-\mathrm{C} 5$ & $118.49(16)$ & $\mathrm{F} 1-\mathrm{C} 16-\mathrm{C} 15$ & $118.42(19)$ \\
\hline
\end{tabular}




\begin{tabular}{|c|c|c|c|}
\hline $\mathrm{C} 1-\mathrm{C} 6-\mathrm{N} 1$ & $120.91(15)$ & $\mathrm{F} 1-\mathrm{C} 16-\mathrm{C} 17$ & $118.38(18)$ \\
\hline $\mathrm{C} 5-\mathrm{C} 6-\mathrm{N} 1$ & $120.60(15)$ & $\mathrm{C} 15-\mathrm{C} 16-\mathrm{C} 17$ & $123.20(18)$ \\
\hline $\mathrm{O} 1-\mathrm{C} 7-\mathrm{N} 1$ & $119.59(15)$ & $\mathrm{C} 16-\mathrm{C} 17-\mathrm{C} 18$ & $117.97(18)$ \\
\hline $\mathrm{O} 1-\mathrm{C} 7-\mathrm{C} 8$ & $121.15(15)$ & $\mathrm{C} 16-\mathrm{C} 17-\mathrm{H} 17$ & $120.7(15)$ \\
\hline $\mathrm{N} 1-\mathrm{C} 7-\mathrm{C} 8$ & $119.23(14)$ & $\mathrm{C} 18-\mathrm{C} 17-\mathrm{H} 17$ & $121.4(15)$ \\
\hline $\mathrm{C} 12-\mathrm{C} 8-\mathrm{C} 7$ & $116.29(15)$ & $\mathrm{C} 17-\mathrm{C} 18-\mathrm{C} 13$ & $121.53(18)$ \\
\hline $\mathrm{C} 12-\mathrm{C} 8-\mathrm{S} 1$ & $123.30(13)$ & $\mathrm{C} 17-\mathrm{C} 18-\mathrm{H} 18$ & $117.9(12)$ \\
\hline $\mathrm{C} 7-\mathrm{C} 8-\mathrm{S} 1$ & $119.93(12)$ & $\mathrm{C} 13-\mathrm{C} 18-\mathrm{H} 18$ & $120.5(12)$ \\
\hline $\mathrm{C} 10-\mathrm{C} 9-\mathrm{N} 1$ & $113.47(14)$ & & \\
\hline $\mathrm{C} 8-\mathrm{S} 1-\mathrm{C} 1-\mathrm{C} 2$ & $-157.17(14)$ & $\mathrm{N} 1-\mathrm{C} 7-\mathrm{C} 8-\mathrm{C} 12$ & $-177.04(15)$ \\
\hline $\mathrm{C} 8-\mathrm{S} 1-\mathrm{C} 1-\mathrm{C} 6$ & $26.38(15)$ & $\mathrm{O} 1-\mathrm{C} 7-\mathrm{C} 8-\mathrm{S} 1$ & $-167.49(13)$ \\
\hline $\mathrm{C} 6-\mathrm{C} 1-\mathrm{C} 2-\mathrm{C} 3$ & $1.4(3)$ & $\mathrm{N} 1-\mathrm{C} 7-\mathrm{C} 8-\mathrm{S} 1$ & $10.7(2)$ \\
\hline $\mathrm{S} 1-\mathrm{C} 1-\mathrm{C} 2-\mathrm{C} 3$ & $-175.12(14)$ & $\mathrm{C} 1-\mathrm{S} 1-\mathrm{C} 8-\mathrm{C} 12$ & $159.13(15)$ \\
\hline $\mathrm{C} 1-\mathrm{C} 2-\mathrm{C} 3-\mathrm{C} 4$ & $-1.1(3)$ & $\mathrm{C} 1-\mathrm{S} 1-\mathrm{C} 8-\mathrm{C} 7$ & $-29.17(15)$ \\
\hline $\mathrm{C} 2-\mathrm{C} 3-\mathrm{C} 4-\mathrm{C} 5$ & $-0.6(3)$ & $\mathrm{C} 7-\mathrm{N} 1-\mathrm{C} 9-\mathrm{C} 10$ & $-87.21(18)$ \\
\hline $\mathrm{C} 3-\mathrm{C} 4-\mathrm{C} 5-\mathrm{C} 6$ & $2.0(3)$ & $\mathrm{C} 6-\mathrm{N} 1-\mathrm{C} 9-\mathrm{C} 10$ & $81.32(18)$ \\
\hline $\mathrm{C} 2-\mathrm{C} 1-\mathrm{C} 6-\mathrm{C} 5$ & $0.0(2)$ & $\mathrm{C} 7-\mathrm{C} 8-\mathrm{C} 12-\mathrm{C} 13$ & $-169.96(16)$ \\
\hline $\mathrm{S} 1-\mathrm{C} 1-\mathrm{C} 6-\mathrm{C} 5$ & $176.34(13)$ & $\mathrm{S} 1-\mathrm{C} 8-\mathrm{C} 12-\mathrm{C} 13$ & $2.0(3)$ \\
\hline $\mathrm{C} 2-\mathrm{C} 1-\mathrm{C} 6-\mathrm{N} 1$ & $179.64(15)$ & $\mathrm{C} 8-\mathrm{C} 12-\mathrm{C} 13-\mathrm{C} 18$ & $-165.58(18)$ \\
\hline $\mathrm{S} 1-\mathrm{C} 1-\mathrm{C} 6-\mathrm{N} 1$ & $-4.0(2)$ & $\mathrm{C} 8-\mathrm{C} 12-\mathrm{C} 13-\mathrm{C} 14$ & $19.9(3)$ \\
\hline $\mathrm{C} 4-\mathrm{C} 5-\mathrm{C} 6-\mathrm{C} 1$ & $-1.7(3)$ & $\mathrm{C} 18-\mathrm{C} 13-\mathrm{C} 14-\mathrm{C} 15$ & $-1.5(3)$ \\
\hline $\mathrm{C} 4-\mathrm{C} 5-\mathrm{C} 6-\mathrm{N} 1$ & $178.67(16)$ & $\mathrm{C} 12-\mathrm{C} 13-\mathrm{C} 14-\mathrm{C} 15$ & $172.96(17)$ \\
\hline $\mathrm{C} 7-\mathrm{N} 1-\mathrm{C} 6-\mathrm{C} 1$ & $-23.7(2)$ & $\mathrm{C} 13-\mathrm{C} 14-\mathrm{C} 15-\mathrm{C} 16$ & $0.7(3)$ \\
\hline $\mathrm{C} 9-\mathrm{N} 1-\mathrm{C} 6-\mathrm{C} 1$ & $169.12(14)$ & $\mathrm{C} 14-\mathrm{C} 15-\mathrm{C} 16-\mathrm{F} 1$ & $-178.73(17)$ \\
\hline $\mathrm{C} 7-\mathrm{N} 1-\mathrm{C} 6-\mathrm{C} 5$ & $155.92(16)$ & $\mathrm{C} 14-\mathrm{C} 15-\mathrm{C} 16-\mathrm{C} 17$ & $0.8(3)$ \\
\hline $\mathrm{C} 9-\mathrm{N} 1-\mathrm{C} 6-\mathrm{C} 5$ & $-11.2(2)$ & $\mathrm{F} 1-\mathrm{C} 16-\mathrm{C} 17-\mathrm{C} 18$ & $178.11(17)$ \\
\hline $\mathrm{C} 6-\mathrm{N} 1-\mathrm{C} 7-\mathrm{O} 1$ & $-162.11(15)$ & $\mathrm{C} 15-\mathrm{C} 16-\mathrm{C} 17-\mathrm{C} 18$ & $-1.5(3)$ \\
\hline $\mathrm{C} 9-\mathrm{N} 1-\mathrm{C} 7-\mathrm{O} 1$ & $5.5(2)$ & $\mathrm{C} 16-\mathrm{C} 17-\mathrm{C} 18-\mathrm{C} 13$ & $0.6(3)$ \\
\hline $\mathrm{C} 6-\mathrm{N} 1-\mathrm{C} 7-\mathrm{C} 8$ & $19.7(2)$ & $\mathrm{C} 14-\mathrm{C} 13-\mathrm{C} 18-\mathrm{C} 17$ & $0.8(3)$ \\
\hline $\mathrm{C} 9-\mathrm{N} 1-\mathrm{C} 7-\mathrm{C} 8$ & $-172.72(14)$ & $\mathrm{C} 12-\mathrm{C} 13-\mathrm{C} 18-\mathrm{C} 17$ & $-174.05(16)$ \\
\hline $\mathrm{O} 1-\mathrm{C} 7-\mathrm{C} 8-\mathrm{C} 12$ & $4.8(2)$ & & \\
\hline
\end{tabular}

Symmetry codes: (i) $-x+1,-y+1,-z$; (ii) $-x-1,-y,-z$; (iii) $x-1, y-1, z$; (iv) $-x,-y+1,-z+1$; (v) $-x+1,-y+1,-z+1$; (vi) $x-1, y, z$; (vii) $x+1, y, z$; (viii) $-x+1,-y+2,-z+1 ;$ (ix) $-x+2,-y+2,-z+1 ;(\mathrm{x})-x,-y+1,-z$.

Hydrogen-bond geometry $\left(A,{ }^{\circ}\right)$

\begin{tabular}{lllll}
\hline$D-\mathrm{H} \cdots A$ & $D-\mathrm{H}$ & $\mathrm{H} \cdots A$ & $D \cdots A$ & $D-\mathrm{H} \cdots A$ \\
\hline $\mathrm{C} 15-\mathrm{H} 15 \cdots \mathrm{F} 1^{\mathrm{ii}}$ & $0.98(2)$ & $2.60(2)$ & $3.306(2)$ & $128.5(17)$ \\
\hline
\end{tabular}

Symmetry code: (ii) $-x-1,-y,-z$. 